\title{
КОНЦЕПЦІЯ ДОРОЖНЬОЇ КАРТИ РОЗВИТКУ ВОДНЕВОЇ ЕНЕРГЕТИКИ УКРАЇНИ НА ПЕРІОД ДО 2035 РОКУ
}

С.О. Кудря ${ }^{1}$, чл.-кор. НАН України, докт. техн. наук, проф., О.О. Рєпкін ${ }^{2}$, Л.В. Яценко ${ }^{1}$, Л.Я. Шинкаренко ${ }^{1}$, М.А. Ткаленко ${ }^{1}$

${ }^{1}$ Інститут відновлюваної енергетики НАН України, 02094, вул. Гната Хоткевича, 20А, м. Київ, Україна.

2Енергетична асоціація «Українська Воднева Рада»

Представлені основні положення конщепиії Дорожньої карти розвитку водневої енергетики України на період до 2035 року щоодо забезпечення використання водню у якості екологічно чистого енергоносія. Проблематика, на розв'язання якої спрямована Дорожня карта розвитку водневої енергетики Украӥни полягає у необхідності створення ефективних систем виробництва, акумулювання, зберігання, транспортування та перетворення водню в енергію необхідної якості із використанням у якості первинного енергоресурсу відновлюваних джерел енергії. Розроблення та реалізація завдань $i$ заходів Дорожньої карти розвитку водневої енергетики України забезпечить зміну структури паливно-енергетичного комплексу України шляхом збільшення в ньому частки відновлюваних джерел енергії, підвищення стабільності роботи енергетичного обладнання, ефективності та надійності електропостачання, а також зменшення антропогенного та техногенного навантаження на довкілля.

Розв'язання поставлених завдань відповідає пріоритетам державної політики - розвитку сфери виробництва енергоносїв з відновлюваних джерел енергії, які можуть забезпечити у 2035 роиі збільшення частки ВДЕ у паливно-енергетичному балансі України до $25 \%$.

Оптимальний варіант досягнення мети Дорожньої карти розвитку водневої енергетики України передбачає розроблення $i$ виконання заходів на період 2020-2035рр., направлених в першу чергу на створення ефективної та економічної інфраструктури постачання споживачів воднем, що використовується в якості енергоносія, та розробку і впровадження дієвого механізму реалізації державної політики у сфері водневої енергетики. Це дасть можливість створити умови для підвищення рівня освоєння енергї відновлюваних джерел, підвищення стабільності у сфері енергопостачання за рахунок накопичення та використання пікової електроенергї̈, а також забезпечити впровадження новітніх технологій на основі водню у транспортній галузі України. Бібл. 10.

Ключові слова: відновлювана енергетика, промислова електроенергетика, акумулювання, воднева енергетика, воднева економіка.

\section{THE CONCEPT OF THE ROADMAP FOR THE DEVELOPMENT OF HYDROGEN ENERGY IN UKRAINE FOR THE PERIOD UNTIL 2035}

\author{
S. Kudrya ${ }^{1}$, corresponding member of the NAS of Ukraine, doctor of technical sciences, professor, O. Riepkin ${ }^{2}$, L. Yatsenko ${ }^{1}$, \\ L. Shynkarenko ${ }^{1}$, M. Tkalenko ${ }^{1}$ \\ ${ }^{1}$ Institute of Renewable Energy of the National Academy of Sciences of Ukraine, \\ 02094, 20A Hnata Khotkevycha St., Kyiv, Ukraine. \\ ${ }^{2}$ Energy Association «Ukrainian Hydrogen Council»
}

The main provisions of the Roadmap for the development of the Hydrogen Energy of Ukraine for the period up to 2035 on ensuring the use of hydrogen as an environmentally friendly energy carrier are presented. The issues addressed by the Hydrogen Energy Roadmap of Ukraine are the need to create efficient systems for the production, storage, storage, transportation and conversion of hydrogen into energy of the required quality, using renewable energy as the primary energy resource. Development and implementation of tasks and activities of the Roadmap for the development of hydrogen energy in Ukraine will change the structure of Ukraine's fuel and energy complex by increasing the share of renewable energy sources, improving the stability of energy equipment, efficiency and reliability of electricity supply, as well as reducing anthropogenic and man-made load on the environment. Meeting these goals is in line with public policy priorities - the development of renewable energy sources that can increase the share of RES in Ukraine's fuel and energy balance by up to $25 \%$ in 2035.

The best option for achieving the goal of the Roadmap for the development of hydrogen energy in Ukraine involves the development and implementation of measures for the period 2020-2035 years, aimed primarily at creating an efficient and economical infrastructure for the supply of consumers with hydrogen, which is used as an energy carrier, and the development and realization of an effective mechanism for the implementation of state policy in the field of hydrogen energy. This will create conditions for increasing the level of energy use of renewable sources, increasing the stability in the field of energy supply through the accumulation and use of peak electricity, as well as ensure the introduction of the latest hydrogen-based technologies in the transport sector of Ukraine. Ref.10.

Keywords: renewable energy, industrial power engineering, storage, hydrogen energy, hydrogen economy. 

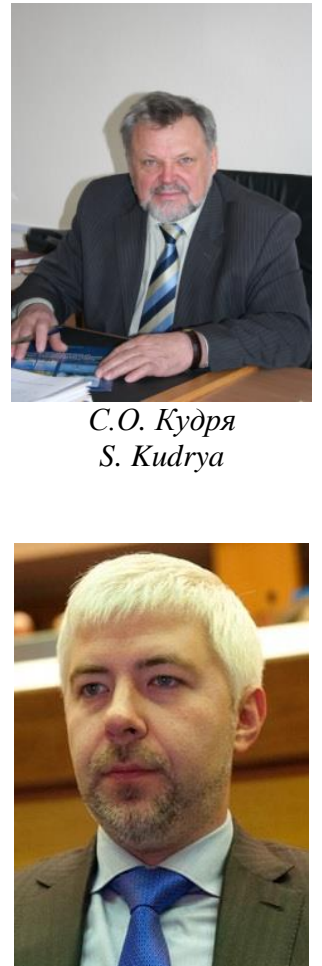

O.O. Репкін

O. Riepkin

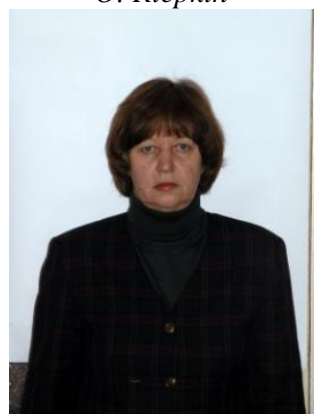

Л.В. Яценко

L. Yatsenko

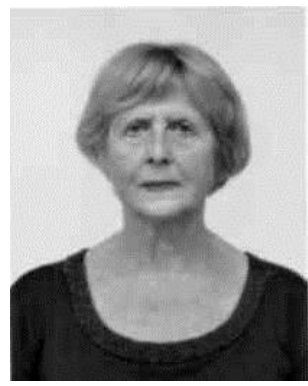

Л.Я. Шинкаренко L. Shynkarenko

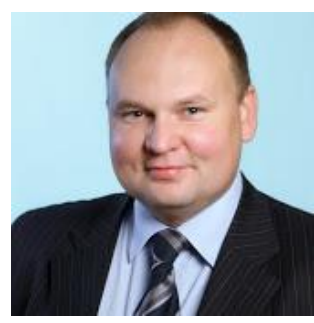

М.Д. Ткаленко M. Tkalenko
Відомості про автора: член-кореспондент НАН України, доктор технічних наук, професор, директор Інституту відновлюваної енергетики НАН України.

Освіта: закінчив в 1971 р. Київський політехнічний інститут за спеціальністю «Технологія електрохімічних виробництв» Наукова сфера: відновлювані джерела енергії, акумулювання енергії, воднева енергетика.

Публікації: 375.

ORCID: 0000-0002-4798-6853

Контакти: +38(044) 206-28-09

e-mail: renewable@ukr.net,

sa.kudria@gmail.com

Відомості про автора: Голова наглядової Ради ТОВ Токмак Солар Енерджі,

Голова Енергетичної асоціації «Українська Воднева Рада».

Освіта: закінчив у 2002 році Національну академію Служби безпеки України за спеціальністю «Правознавство».

Наукова сфера: сонячна енергетика, воднева енергетика

Публікації: 5.

ORCID: 0000-0002-3448-6729

Контакти: +38068 8993399

e-mail: a.riepkin@me.com

Відомості про автора: науковий співробітник Інституту відновлюваної енергетики НАН України.

Освіта: закінчила в 1976 р. Київський політехнічний інститут за спеціальністю «Технологія електрохімічних виробництв» Наукова сфера: відновлювані джерела енергії, акумулювання енергії, воднева енергетика.

Публікації: 80.

ORCID: 0000-0001-7022-1579

Контакти: +38(044) 206-28-09

e-mail: renewable@ukr.net

Відомості про автора: молодший науковий співробітник Інституту відновлюваної енергетики НАН України.

Освіта: закінчила в 1978 р. Київський політехнічний інститут за спеціальністю «Технологія електрохімічних виробництв» Наукова сфера: відновлювані джерела енергії, акумулювання енергії, воднева енергетика

Публікації: 17.

ORCID: 0000- 0003-2018-3329

Контакти: +38(044) 206-28-09

e-mail: renewable@ukr.net

Відомості про автора: старший науковий співробітник Інституту відновлюваної енергетики НАН України.

Освіта: закінчив в 1996 р. Київський політехнічний інститут за спеціальністю «Технічна електрохімія».

Наукова сфера: відновлювані джерела енергії, акумулювання енергії, воднева енергетика.

Публікації: 77.

ORCID: 0000-0003-0698-5739

Контакти: +38(044) 206-28-09

e-mail: renewable@ukr.net
Author information: corresponding member of NAS of Ukraine, Doctor of Technical

Sciences, Professor, Director of the Institute of Renewable Energy NAS of Ukraine.

Education: granduated from the Kyiv

Polytechnic Institute in 1979 with a degree «Electrochemical Productions Technology».

Research area: renewable energy sources, energy storage, hydrogen energy.

Publications: 375 .

ORCID: 0000-0002-4798-6853

Contacts: +38 (044) 206-28-09

e-mail: renewable@ukr.net,

sa.kudria@gmail.com

Author information: Chairman of the Board of the company Tokmak Solar Energy

Head of the Energy Association «Ukrainian Hydrogen Council»

Education: graduated from the National Academy of Security Service of Ukraine in 2002 with a degree in Law.

Research area: solar power, hydrogen power. Publications: 5.

ORCID: 0000-0002-3448-6729

Contacts: +38068 8993399

e-mail: a.riepkin@me.com

Author information: researcher at Institute of Renewable Energy, National Academy of Sciences of Ukraine.

Education: granduated from the Kyiv Polytechnic Institute in 1976 with a degree «Electrochemical Productions Technology». Research area: renewable energy sources, energy storage, hydrogen energy.

Publications: 80

ORCID: 0000-0001-7022-1579

Contacts: +38 (044) 206-28-09

e-mail: renewable@ukr.net

Author information: junior researcher at Institute of Renewable Energy, National Academy of Sciences of Ukraine.

Education: granduated from the Kyiv Polytechnic Institute in 1978 with a degree «Electrochemical Productions Technology». Research area: renewable energy sources, energy storage, hydrogen energy.

Publications: 17 .

ORCID: 0000- 0003-2018-3329.

Contacts: +38 (044) 206-28-09

e-mail: renewable@ukr.net

Author information: researcher fellow at Institute of Renewable Energy, National Academy of Sciences of Ukraine.

Education: granduated from the Kyiv Polytechnic Institute in 1996 with a degree «Technical electrochemistry».

Research area: renewable energy sources, energy storage, hydrogen energy.

Publications: 77.

ORCID: 0000-0003-0698-5739

Contacts: +38 (044) 206-28-09

e-mail: renewable@ukr.net 
Вступ. У даний час у світі все ширше починається використання водню як універсального екологічно чистого енергоносія для вирішення важливих енергетичних та екологічних проблем i зменшення ризику, пов'язаного із збагаченням атмосфери вуглекислим газом. Використання водню дає можливість створення як короткострокових, так i довгострокових міжсезонних запасів енергії в енергосистемах на основі відновлюваних джерел енергії та в традиційній енергетиці.

Сучасний комплекс технологій водневої енергетики включає наступне: отримання водню, його накопичення та зберігання, транспортування та використання. Отримувати водень для енергетичних потреб найбільш ефективно при застосуванні методу електролітичного розкладу води. Сучасні електролізні установки мають досить високі технічні характеристики та зручні в обслуговуванні. У якості первинного джерела електроенергії може використовуватись як надлишкова електроенергія від відновлюваних джерел енергії, так і пікова енергія традиційних електростанцій. Крім того, перспективним $\epsilon$ створення суто водневих енергоакумулюючих систем на основі відновлюваних джерел енергії (ВДЕ), розташованих у тому числі в важкодоступних для подачі електроенергії районах [1-10].

Постановка завдання. Визначення основних засад щодо розроблення та реалізації завдань і заходів Дорожньої карти розвитку водневої енергетики України (далі - Дорожня карта) на період до 2035 року із забезпечення використання водню у якості екологічно чистого енергоносія, яка, 3 урахуванням положень «Енергетичної стратегії України на період до 2035 року «Безпека, енергоефективність, конкурентоспроможність», згідно розпорядження КМУ № 497-р від 06.06.2018 «Про затвердження плану заходів 3 реалізації етапу «Реформування енергетичного сектору (до 2020 року)» повинна забезпечити досягнення основної мети підвищення ефективності освоєння енергії відновлюваних джерел та підвищення стабільності енергосистеми України за рахунок впровадження систем акумулювання.

Основні положення Дорожньої карти розвитку водневої енергетики України на період до 2035 року. Метою Дорожньої карти $\epsilon$ створення водневої енергетики як нової енергетичної підгалузі України, яка шляхом впровадження новітніх технологій, створення вітчизняної наукової, науково-технічної, технологічної та виробничої інфраструктури поступово забезпечить значну частку потреб енергетичної та транспортної галузей України в екологічно чистому енергоносії. Це сприятиме розвитку відновлюваної енергетики як пріоритетного напряму державної політики, i, відповідно, зменшенню споживання органічного палива та поліпшенню стану довкілля. Строк виконання заходів Дорожньої карти розвитку водневої енергетики України - 16 років, на період з 2020 по 2035 роки.

Досягнення мети Програми забезпечується за рахунок реалізації державної політики у сфері водневої енергетики, створення економічних, фінансових та інституційних механізмів, які визначаються Дорожньою картою і обумовлюють діяльність всіх суб'єктів господарювання в напрямку забезпечення постійного прогресу в даній сфері.

Виконання заходів Дорожньої карти дасть можливість:

- розробити та впровадити ефективні енергосистеми на основі відновлюваних джерел енергії, 3 використанням систем акумулювання, зберігання, транспортування та використання водню різного виду та потужності, так званий «зелений» водень»;

- розробити та впровадити системи акумулювання, зберігання, транспортування та використання водню різного виду та потужності в традиційній енергетиці для накопичення пікової електроенергії, так званий «промисловий водень»;

- розробити та впровадити системи акумулювання та використання водню різного виду та потужності в транспортній галузі;

- розробити та впровадити системи трубопровідного транспортування водню, у тому числі у якості добавок до природного газу;

- досягти 25-ти відсоткової частки водню в газотранспортній системі (ГТС) України;

- розробити та впровадити механізми державного управління і регулювання у сфері водневої енергетики;

- розробити законодавчі та нормативноправові акти, спрямовані на розвиток водневої енергетики;

- забезпечити більш широке залучення об'єктів інтелектуальної власності до процесу розвитку водневої енергетики;

- підвищити рівень конкурентоспроможності об'єктів відновлюваної енергетики;

- виконати зобов'язання України щодо рівня використання ВДЕ відповідно вимог Європейського Союзу;

- підвищити рівень енергетичної не залежності України за рахунок широкомасштабного освоєння енергії відновлюваних джерел, 
збільшивши їх частку у паливно-енергетичному балансі України.

Для впровадження ефективних заходів щодо механізму реалізації Дорожньої карти, зокрема економічно-правового, нормативно-методичного, інформаційного, кадрового та організаційнокерівного забезпечення, необхідно виконання таких основних завдань:

- проведення загальнодержавного аудиту різних галузей енергоринку України для встановлення можливих напрямів та обсягів впровадження техніки та технологій водневої енергетики до 2035 року;

- визначення основних напрямів розвитку водневої енергетики;

- створення бази даних щодо наявності та ефективності енергетичного обладнання для виробництва, зберігання, транспортування та споживання водню за всіма особливо перспективними та ефективними напрямами розвитку водневої енергетики та які вже законодавчо прийняті в $\mathrm{CC}$;

- створення бази даних обладнання на основі відновлюваних джерел енергії, придатних для виробництва «зеленого» водню за рахунок електролізу води;

- створення бази даних об'єктів традиційної енергетики, на яких є доцільним виробництво промислового водню за рахунок використання пікової електроенергії;

- розробка науково-технічних проектів на основі зразків обладнання водневої енергетики світового рівня для виробництва, зберігання, транспортування водню, апробація та розробка рекомендацій щодо їх впровадження;

- будівництво базових демонстраційних об'єктів водневої енергетики за прийнятними для виробництва «зеленого» водню напрямами використання ВДЕ;

- розробка нормативно-правової бази та законів прямої і непрямої дії, що сприяють впровадженню розробок водневої енергетики на основі ВДЕ;

- проведення науково-технічних досліджень щодо створення вітчизняної техніки та технологій водневої енергетики;

- формування інвестиційної політики у сфері водневої енергетики;

- залучення коштів усіх зацікавлених суб'єктів господарювання та забезпечення сприятливих умов для впровадження запропонованих заходів;

- формування і реалізація управління у сфері водневої енергетики;
- організація контролю за ефективністю здійснення заходів Дорожньої карти та використання коштів;

- створення сертифікаційної та метрологгічної бази;

- створення промислової бази для виробництва технічних пристроїв та обладнання, монтажу, експлуатації, ремонту та сервісу;

- створення профільної інфраструктури водневої енергетики на основі вже існуючих навчальних, проектно-конструкторських та науково-дослідницьких організацій;

- створення освітньої бази;

- сприяння утворенню приватних та громадських організацій по розповсюдженню та популяризації водневої енергетики

Для ефективного впровадження Дорожньої карти необхідно виконання ряду основних завдань, що сприятиме створенню ефективних механізмів їх реалізації, зокрема нормативноправового, економічного, методичного, інформаційного, кадрового та організаційнокерівного забезпечення:

- удосконалення законодавчо-правової та нормативно-технічної бази;

- організація науково-технічного забезпечення;

- організація інформаційного забезпечення та освіти;

- організація управління та контролю за виконанням Дорожньої карти;

- визначення механізмів реалізації та фінансового забезпечення Дорожньої карти;

- застосування методів економічного стимулювання;

- використання системи міжнародного співробітництва;

- створення методичного забезпечення;

- визначення потенціалу первинних енергетичних ресурсів для виробництва «зеленого» водню;

- впровадження першочергових розробок в галузі водневої енергетики на основі ВДЕ.

Питання розвитку водневої енергетики України передбачається розв'язати шляхом виконання заходів щодо основних напрямів реалізації проектів водневої енергетики високої енергоефективності із використанням різних відновлюваних джерел енергії та систем акумулювання i використання водню різного виду та потужності.

Дорожньою картою буде передбачено виконання значного обсягу науково-дослідних, дослідно-конструкторських робіт, опрацювання нормативно-технічної документації дослідно- 
промислового будівництва, впровадження найбільш ефективних проектів у промислову експлуатацію, а також використання стандартних методів адміністративного контролю прийнятою в країні системою організації роботи і контролю виконання програм такого рівня 3 урахуванням міжгалузевого характеру деяких завдань Дорожньої карти.

Керівництво цими роботами і контроль за їх виконанням покладаються на замовників i виконавців, а загальну організацію і координацію всіх заходів, передбачених Дорожньою картою, має здійснювати відповідно до покладених на нього обов'язків Державне агентство 3 енергоефективності та енергозбереження України. Науково-технічне та інформаційне забезпечення Програми доцільно покласти на Національну Академію наук України, зокрема на Інститут відновлюваної енергетики НАН України як головну організацію 3 розробки Дорожньої карти.

Організаційне формування i забезпечення галузевих та регіональних розділів Дорожньої карти здійснюватимуть відповідні центральні та місцеві органи виконавчої влади.

Реалізація завдань Дорожньої карти потребує постійного контролю та щорічного коригування складу завдань 3 метою запобігання неефективних витрат, своєчасного виявлення заходів, впровадження яких неефективне, та включення нових перспективних проектів. Для цього необхідно створити систему оперативного збору та обробки інформації про хід виконання Дорожньої карти.

Науково-технічне забезпечення Дорожньої карти здійснюється за такими основними напрямами:

- координація всіх робіт 3 наукового супроводження Дорожньої карти;

- удосконалення існуючого та створення вітчизняного устаткування та технологій, що забезпечить ефективний розвиток водневої енергетики України із використанням енергії ВДЕ;

- створення систем аналітично-інформаційного забезпечення науково-технічного розвитку водневої енергетики;

- створення системи метрологічного та сертифікаційного забезпечення.

Для створення ефективних водневих енергосистем на основі ВДЕ та вирішення питань ефективності і доцільності реалізації конкретних проектів та заходів необхідна розробка методичного та інформаційно-аналітичного забезпечення.
Зміни в законодавстві і нормативній базі, стан розвитку економіки, кон'юнктура ринку, екологічні та інші фактори також вимагатимуть внесення 3 часом у Дорожню карту певних коректив. Тому необхідно створити інформаційно-аналітичну систему, завданнями якої є:

- постійний моніторинг і супровід виконання заходів Дорожньої карти;

- збір, накопичення та обробка даних, що стосуються Дорожньої карти;

- забезпечення інформаційних запитів щодо наявності в системі інформації;

- проведення відповідних аналітичних та прогнозуючих розрахунків;

- інформаційна підтримка проектувальників і виробників водневих енергоефективних технологій, машин та обладнання.

Наявність такої бази даних обумовить прискорення науково-дослідних, проектно-конструкторських та експериментальних робіт по впровадженню устаткування на основі водню та ВДЕ.

Основні завдання системи науковотехнічного супроводження такі:

- контроль та координація виконання етапів та завдань Дорожньої карти;

- своєчасне внесення уточнень;

- визначення пріоритетності завдань Дорожньої карти на кожному етапі іiі реалізації i формування політики інвестування;

- поточне стеження за ресурсним забезпеченням завдань Дорожньої карти 3 оцінкою реальності їх виконання у встановлені терміни;

- щорічне звітування перед Державним агентством 3 енергоефективності та енергозбереження України.

Ефективність супроводження Дорожньої карти залежить від досконалості створеної системи прямого та зворотнього зв'язку між створеною при Держенергоефективності робочою групою супроводження та виконавцями, механізму впливу на виконавців, а також бази даних показників Дорожньої карти та і1і програмного забезпечення. Перш за все необхідно забезпечити систематичне надходження уніфікованої інформації про хід виконання завдань Дорожньої карти і розробити форми звітності.

База даних Дорожньої карти повинна включати нормативну, звітно-статистичну та прогнозну інформацію на макроекономічному, регіональному, галузевому та продуктовому рівнях (обсяги виробництва i послуг, енергомісткість, питомі витрати палива і енергії тощо), інформацію щодо сучасного стану розробок обладнання (виробник, обсяги виробництва, енергопоказники, вартість 
та інше) i опис та характеристику заходів (витрати на реалізацію, ефективність і т.і.).

Фінансування заходів Дорожньої карти передбачається здійснювати за рахунок державного бюджету, власних коштів суб'єктів господарювання, вітчизняних i міжнародних інвестицій, грантів та інших джерел, не заборонених чинним законодавством України.

В процесі реалізації Дорожньої карти розвитку водневої енергетики України на період до 2035 року пропонується застосування диференційованого підходу при фінансуванні, враховуючи при цьому пріоритетність впровадження напрямів водневої та відновлюваної енергетики, який передбачає поєднання традиційних адміністративних методів 3 ринковими, що базуються на застосуванні конкурентності в питаннях розподілу фінансових ресурсів.

Враховуючи недостатній ступінь підготовленості техніки та технологій водневої енергетики до впровадження в різних галузях народного господарства i в побуті, на першому етапі виконання Дорожньої карти необхідно проведення розрахунково-аналітичних та науково-дослідних робіт. Пропонованується наступна схема послідовного виконання робіт:

- розрахунково-аналітичні та науководослідні розробки;

- проектно-конструкторські роботи;

- будівництво і апробація демонстраційних об'єктів;

- підготовка до впровадження у промислову експлуатацію (опрацювання ТЕО, оформлення замовлення на виробництво обладнання та устаткування, визначення джерел фінансування;

- будівництво і експлуатація промислових зразків водневої енергетики.

Міжгалузевий аспект Дорожньої карти враховує необхідність розподілу відповідальності між міністерствами i відомствами, що мають відношення до виконання Дорожньої карти, передбачає поєднання традиційних адміністративних методів 3 ринковими методами, які базуються на застосуванні конкурентності в питаннях розподілу фінансових ресурсів.

Конкретний набір важелів фінансовоекономічних механізмів реалізації заходів Дорожньої карти визначається умовами, в яких вони будуть здійснюватись, станом розвитку окремих підприємств, галузей і економіки країни в цілому, фінансовими можливостями держави i забезпечується гарантіями уряду.

Визначення джерел i напрямів фінансового забезпечення заходів, передбачених в Дорожній карті, буде уточнюватись при щорічному опрацюванні прогнозів соціально-економічного розвитку галузей, регіонів України, а також при складанні державного бюджету.

При обмеженості інвестиційних ресурсів реалізацію заходів Дорожньої карти необхідно проводити в першу чергу в галузях, що забезпечують нагальні потреби суспільства - в паливно-енергетичному комплексі, транспортній галузі, соціальній і комунальній сфері.

Обсяг фінансування Дорожньої карти на кожний iз зазначених періодів додатково буде визначатись i коригуватись в подальшому iз урахуванням пріоритетності напрямів розвитку сфери виробництва водню 3 відновлюваних джерел енергіi, науково-технічного прогресу та розвитку технологій у відповідних періодах реалізації Дорожньої карти.

Висновки. Розробка та реалізація завдань і заходів Дорожньої карти розвитку водневої енергетики України забезпечить ефективні умови використання водню в якості енергоносія в енергосистемах відновлюваної енергетики та в якості моторного палива для транспортних засобів. Це дозволить скоротити обсяги споживання традиційного органічного палива, а перспективи розвитку відновлюваної енергетики при наявності відповідних пільг дозволяють говорити про досягнення досить прийнятних вартісних показників.

Екологічна значимість результатів реалізації Дорожньої карти полягає в значному зменшенні шкідливих викидів в атмосферу, що утворюються при згорянні органічного палива. Переваги водневої енергетики на основі відновлюваних джерел енергіï у сфері екологіï повинні забезпечити додатковий економічний ефект.

Соціальна значимість реалізації Дорожньої карти полягає у створенні додаткових робочих місць як в процесі, так $\mathrm{i}$ в результаті ऑii виконання в галузях наукової, виробничої, культурно-освітньої, правової, державної та громадської діяльності, а також у поліпшенні рівня надання послуг у соціальній і комунальній сферах України.

1. Водород. Свойства, получение, хранение, транспортирование, применение. Под редакцией Гамбурга Д.М. - Москва.: Химия, 1989. - 671 с.

2. Украина: эффективность малой энергетики. Издание Энергетического Центра ЕС в Киеве. 1996.- 280с.

3. Дмитриев А.Л., Прохоров Н.С. Перспективы применения водорода в качестве энергоносителя. "Химическая промышленность", т. 80, №10 (455), 2003. - С. 27.

4. Мхітарян Н.М., Кудря С.О., Яценко Л.В., Шинкаренко Л.Я., Будько В.І. Перспективи використання водню у відновлюваній енергетиці // Відновлювана енергетика. - 2008. - №3 (14). - с. 5 - 15. 
5. Мухачев А.П., Щур Д.В. Альтернативные источники энергии и водородная энергетика /Энергосбережение / №5. 2007. - С. $15-19$.

6. Олійник Я. Б. Основи екології: підручник / Я. Б. Олійник, П. Г. Шищенко, О. П. Гавриленко. - К.: Знання, 2012. $-558 \mathrm{c}$.

7. Межевич А.С., Руженцев И.В. Развитие водородной энергетики как одно из перспективных направлений решения развивающегося на планете экологического и экономического кризиса. /Энергосбережение. Энергетика Энергоаудит. / №11 (57). - 2008. - С. 35-42.

8. Баранников А.А. Перспективы водородной энергетики /Энергосбережение / №7. - 2012. - С. 22-24.

9. Фундаментальні аспекти відновлювано-водневої енергетики і паливно-комірчаних технологій / за загальною редакцією Ю.М. Солоніна. - К.: «КІМ», 2018. - 260с.

10. Кудря С.О., Рєпкін О.О., Ткаленко М.Д., Шинкаренко Л.Я., Пепелов О.В. Напрями розвитку водневої енергетики та водневої економіки в Україні // Відновлювана енергетика та енергоефективність XXI століття : XX-a міжнар. конф., 15-16 травня 2019 р., : тези доп. - м. Київ, 2019. - C. $58-65$

\section{REFERENCES}

1. Hamburg D.M. Vodorod. Svoystva, polucheniye khraneniye, transportirovaniye, primeneniye. [Hydrogen Properties, receipt, storage, transportation, application] Moscow. Chemistry. 1989. 671 p. [in Russian].

2. Ukraina: effektivnost maloy energetiki. [Ukraine: small energy efficiency]. The publication of the EU Energy Center in Kiev. 1996. 280 p. [in Russian].

3. Dmitriyev A.L., Prokhorov N.S. Perspektivy primeneniya vodoroda $\mathrm{v}$ kachestve energonositelya. [Prospects for the use of hydrogen as an energy carrier]. Khimicheskaya promyshlennost. T. 80. No. 10(455). 2003. 27 p. [in Russian].

4. Mkhitaryan N.M., Kudrya S.O., Yatsenko L.V., Shynkarenko L.YA., Budko V.I. Perspektyvy vykorystannya vodnyu u vidnovlyuvaniy enerhetytsi. [Prospects for the use of hydrogen in renewable energy]. Vidnovluvana energetika. 2008 No.3(14). Pp. 5-15. [in Ukrainian].

5. Mukhachev A.P., Shchur D.V. Alternativnyye istochniki energii i vodorodnaya energetika. [Alternative energy sources and hydrogen energy]. Energosberezheniye. 2007. No. 5. Pp. 15-19. [in Russian].

6. Oliynyk Ya. B., Shyshchenko P.H., Havrylenko O.P. Osnovy ekolohiyi. [Fundamentals of ecology]. textbook. K Znannya. 2012. 558 p. [in Ukrainian].

7. Mezhevich A.S., Ruzhentsev I.V. Razvitiye vodorodnoy energetiki kak odno iz perspektivnykh napravleniy resheniya razvivayushchegosya na planete ekologicheskogo ekonomicheskogo krizisa. [The development of hydrogen energy as one of the promising directions for solving the environmenta and economic crisis developing on the planet] Energosberezheniye. Energetika. Energoaudit. No. 11(57). 2008 Pp. 35-42. [in Russian].

8. Barannikov A.A. Perspektivy vodorodnoy energetiki. [Prospects for hydrogen energy]. Energosberezheniye. No.7. 2012. Pp. 22-24. [in Russian].

9. Solonina Yu.M. Fundamentalni aspekty vidnovlyuvano-vodnevoyi enerhetyky i palyvno-komirchanykh tekhnolohiy. [Fundamental Aspects of Renewable-Hydrogen Energy and Fuel-Cell Technologies]. K. «KIM». 2018. 260 p. [in Ukrainian].
10. Kudrya S.O., Riepkin O.O., Tkalenko M.D., Shynkarenko L.Ya., Pepelov O.V. Napryamy rozvytku vodnevoyi enerhetyky ta vodnevoyi ekonomiky v Ukrayini. [The directions of development of hydrogen energy and hydrogen economy in Ukraine]. Renewable energy and energy efficiency of XXI century: XX-th international. Conf. May 15-16.2019. These suppl. Kyiv. 2019. P. 58-65. [in Ukrainian].

\section{КОНЦЕПЦИЯ ДОРОЖНОЙ КАРТЫ РАЗВИТИЯ ВОДОРОДНОЙ ЭНЕРГЕТИКИ УКРАИНЫ НА ПЕРИОД ДО 2035 ГОДА}

С.А. Кудря ${ }^{1}$, чл.-кор. НАН Украины, докт. техн. наук, проф., А.А. Репкін ${ }^{2}$, Л.В. Яценко ${ }^{1}$, Л.Я. Шинкаренко ${ }^{1}$, М.А. Ткаленко ${ }^{1}$

${ }^{1}$ Институт возобновляемой энергетики НАН Украины, 02094, ул. Гната Хоткевича 20A, г. Киев, Украина.

2Энергетическая ассоциация «Українська Воднева Рада».

Представлены основные положения концепиии Дорожной карты развития водородной энергетики Украины на период до 2035 года по использованию водорода в качестве экологически чистого энергоносителя. Проблематика, на решение которой направлена Дорожная карта развития водородной энергетики Украины заключается 6 необходимости создания эффективных систем производства, аккумулирования, хранения, транспортировки и превращения водорода в энергию необходимого качества с использованием в качестве первичного энергоресурса возобновляемых источников энергии. Разработка и реализация заданий и мероприятий Дорожной карты развития водородной энергетики Украины обеспечит изменение структуры топливноэнергетического комплекса Украины путем увеличения в нем доли возобновляемых источников энергии, повымения стабильности работы энергетического оборудования, эффективности и надежности электроснабжения, а также уменьшения антропогенной и техногенной нагрузки на окружаюшую среду.

Решение поставленных задач отвечает приоритетам государственной политики - развитию сферь производства энергоносителей из возобновляемых источников энергии, которые могут обеспечить в 2035 году увеличение доли ВИЭ в топливно-энергетическом балансе Украинь до $25 \%$.

Оптимальный вариант достижения иели Дорожной карть развития водородной энергетики Украинь предусматривает разработку и выполнение мероприятий на период 2020-2035рр., направленных в первую очередь на создание эффективной и экономичной инфраструктуры снабжения потребителей водородом, используемым 6 качестве энергоносителя, а также разработку и внедрение действенного механизма реализаиии государственной политики в сфере водородной энергетики. Это даст возможность создать условия для повышения уровня освоения энергии возобновляемых источников, повышения стабильности в сфере энергоснабжения за счет накопления u использования пиковой электроэнергии, a также обеспечить внедрение новейших технологий на основе водорода в транспортной отрасли Украины. Библ. 10.

Ключевые слова: возобновляемая энергетика, промышленная электроэнергетика, аккумулирование, водородная энергетика, водородная экономика. 